\title{
ASSESSMENT PENGGUNAAN ALAT-ALAT ANALISIS PENELITIAN TESIS MAHASISWA PASCASARJANA UNIVERSITAS PGRI ADIBUANA SURABAYA
}

\author{
Djoko Adi Walujo ${ }^{1)}$, Yitno Utomo ${ }^{2)}$ \\ ${ }^{1) 2)}$ Program Studi Teknik Industri \\ Universitas PGRI Adi Buana Surabaya \\ Email: adiwalujo@gmail.com
}

\begin{abstract}
Abstrak
Kajian ini bertujuan untuk mengetahui secara dini tingkat kesesuaian pemilihan alat analisis dengan data yang dilakukan dalam penulisan tesis. Selanjutnya kajian ini mencermati pemahaman mahasiswa terkait dengan jenis data dan kategorikal skala data, yang digunakan sebagai dasar untuk menentukan instrumen penelitian serta analisanya. Kemudian juga mendeskripsikan kesalahan yang paling dominan dari antara bidang kesalahan, dan menelusuri penyebab terjadinya kesalahan.

Hasil kajian menunjukkan, bahwa (1) pemilihan alat analisis kurang memperhatikan keterkaitan dengan topik penelitian, (2) Pemilihan alat analisis tidak diprediksikan dengan tingkat kebutuhan data, (3) Kurang memahami skala variabel, sehingga cenderung memaksakan alat analisis, (4) Terdapat beberapa kerancauan antara pengungkapan problema korelasional dengan problema penelitian yang mengungkap pengaruh variabel antar variabel, (5) Kurang pemahaman terhadap pola hubungan pemilihan instrumen penelitian dengan topik, (6) Pemilihan instrumen yang berlebihan, yang pada dasarnya tidak memiliki pengaruh pada hasil, sehingga tidak berguna/tidak digunakan, dan (7) Kesadaran pentingnya uji validitas dan reliabilitas sangat tinggi.
\end{abstract}

Kata Kunci: Alat Analisis, Skala Variabel, Tingkat Kesalahan.

\begin{abstract}
This study aims to determine the appropriateness of the level of early elections with the data analysis tools made in writing thesis. Furthermore, this study examine student understanding related to the type of data scale categorical data, which used as the basis for determining the research instruments and analysis. Then also describe the most dominant error of the field error, and trace the cause of the error.

The results showed that (1) the selection of analysis tools less attention to the linkages with the research topic, (2) Choose the analysis tools are not predicted by the level of data needs, (3) Less understood scale variable, so it tends to impose an analytical tool, (4). Some error correlation between the disclosure of the problems with research problems that reveal the influence of variables between variables, (5) Lack of understanding of the patterns of relationships with instrument selection of research topics, (6) Excessive research instruments, essentially has no effect on the outcome, so it is useless, and (7) Awareness of the importance of test validity and reliability is very high.
\end{abstract}

Keywords: Analysis Tools, Scale Variabless, Error Rate. 


\section{PENDAHULUAN}

Penelitian ilmiah pada dasarnya merupakan cara ilmiah untuk mendapatkan data dengan tujuan dan kegunaan tertentu. Kegiatan penelitian didasarkan pada ciri-ciri keilmuan, yaitu rasional, empiris, dan sistematis. Penelitian harus rasional artinya penelitian ini dengan dilakukan dengan cara-cara yang masuk akal, sehingga terjangkau oleh penalaran manusia. Empiris berarti cara-cara yang dilakukan dalam penelitian dapat diamati oleh indera manusia, sehingga orang lain dapat mengamati dan mengetahui caracara yang digunakan. Sedangkan sistematis adalah proses yang digunakan dalam penelitian ini menggunakan langkah-langkah tertentu yang bersifat logis, ada beberapa langkah yang harus dilakukan peneliti dalam penelitiannya. Kesemua langkah-langkah tersebut harus dilewati oleh peneliti, diantaranya yaitu teknik dalam menganalisis data. (Ericson, 1981)

Penelitian hendaknya memiliki karakteristik yang obyektif, ketepatan, verifikasi, memiliki penjelasan, empirik, logis dan kondisional, hal ini sesuai sesuai dengan pendapat McMillan dan Schumacher (2001) memang penelitian yang obyektif harusnya tidak bias, selanjutnya harus memiliki ketepatan baik segi bahasayang digunakan maupun unsure validitas dan reliabilitasnya. Verifikasi dimaksudkan agar penelitian juga mampu dilanjutkan untuk peneliti berikutnya, Empirisme dibuktikan dengan pengalaman praktis bukan sebuah rekayasa. Logis lebih pada penjelasan dan penalaran yang logis jika melakukan sebuah penelitian sedangkan kondisional itu memiliki kecenderungan bahwa penelitian tidak boleh miskonsepsi sehingga memiliki juga sedikitnya kebenaran yang mutlak, walaupun unsurnya masih diperlukan analisis lanjutan.

Prosedur atau langkah-langkah pokok penelitian pendidikan tidak terlepas dari metode ilmiah (scientific method). Tujuannya digunakan untuk memecahkan masalah-masalah berdasarkan prinsip-prinsip ilmiah (Arifin, 2011). Namun juga dalam kehidupan sehari-hari proses memecahkan masalah dengan metode non-ilmiah, seperti ; akal, prasangka, intuisi dan trial and error. Namun untuk sebuah penelitian terutama yang diperuntukkan pada penelitian tingkat lanjut seperti pada pascasarjana, sangat dimungkinkan untuk diperlukan alat analisis lebih dari satu, hal ini bertujuan agar keputusan penelitian akan lebih baik dan sempurna.

Kesalahan dalam menggunakan alat-alat statistik, akan memberikan dampak pada tingkat kesahihan penelitia, hingga hasil penelitian tidak dapat mencerminkan hasil yang sesungguhnya. Pada hakikatnya statistik adalah alat dalam penelitian, oleh karena itu, harus digunakan secara tepat. Dari berbagai pengalaman empiri selama melaksanakan tugas pembimbingan mahasiswa, didapat varian kesalahan sebagai berikut:

1. Memilih alat-alat statistik yang tidak tepat atau benar untuk menganalisis proposal.

2. Mengumpulkan data penelitian, dan kemudian mencoba menemukan teknis statistik yang dapat digunakan dalam analisis.

3. Hanya menggunakan satu prosedur statistik pada saat justru banyak prosedur yang dapat dipakai untuk menganalisis data. Juga sebaliknya menggunakan berbagai macam alat analisis, yang seharusnya tidak.

4. Menggunakan asumsi-asumsi statistik pada saat tidak diperlukan.

5. Terlalu mementingkan perbedaan-perbedaan kecil mengenai signifikansi statistik.

6. Mahasiswa menghindari analisis korelasi jika standar korelasi 
momen produk (productmoment) tidak dapat dipakai.

7. Menggunakan teknik korelasi yang tidak tepat, seperti menggunakan korelasi biserial pada saat seharusnya menggunakan korelasi widespread biserial.

8. Menggunakan tabel signifikan momen produk untuk menginterpretasi perhitungan bukan korelasi Pearson. Oleh karena korelasi bukan Pearson mempunyai standar kesalahan lebih besar daripada korelasi momen produk, kesalahan ini mengakibatkan estimasi yang berlebihan terhadap estimasi signifikansi dari koefisien yang diinterpretasikan.

9. Menggunakan koreksi untuk attenuation pada situasi yang kurang tepat untuk menampilkan hasil yang lebih signifikan.

Realitas yang sering terjadi, ketika tuntutan waktu pembimbingan yang relatif pendek maka dapat menurunkan tingkat kecermatan mahasiswa dalam memilih alat analisis. Hal ini juga diperparah, karena mahasiswa melakukan replikasi terhadap tesis-tesis yang ada, tanpa perlakukan telaah yang mendalam. Sisi lain juga ditengarahi adanya pemaksaan alat analisis karena mahasiswa kurang memahami metodologi penelitian dan statistik.

\section{METODE}

Jenis kajian ini sebenarnya pendekatan deskriptif dimana dalam kajian ini tidak melalukan pengujian terhadap hipotesis (Manning, 1993). Menurut Arikunto (2013) bahwa penelitian deskriptif tidak dimaksudkan untuk menguji hipotesis tertentu, tetapi hanya menggambarkan "apa adanya" tentang suatu variabel penelitian, gejala dan keadaan. Untuk penelitia ini memang dilkukan pengamatan langsung pada obyek penelitian berupa pengamatan jenis-jenis analisa yang dipergunakan mahasiswa pascasarjana.

Populasi dalam penelitian ini sejumlah 45 tesis, yang dengan menggunakan teknik sampling berupa purposive sampling yaitu sampel bertujuan, yang hanya ditujukan pada tesis-tesis yang berjenis kuantitatif sehingga didapatkan sampel sebanyak 39 tesis. Menurut Sudjana (2007) bahwa purposive sampling merupakan cara efektif dan sederhana untuk memastikan kebutuhan sampel penelitian, hanya didasarkan pada tujuan tertentu sesuai keinginan peneliti.

Analisis data yang diterapkan dalam penelitian ini karena bersifat deskriptif maka dipergunakan analisa prosentase, selanjutnya memang dalam data kualitatif itu dikategorikan bersarkan kualitas objek yang diteliti, seperti baik, buruk dan sebagainya. Dalam pembahasan penelitian yang direncanakan memang untuk mengetahui sebaran berapa banyak mahasiswa yang mempergunakan alatalat analisa statistik berdasarkan pemilihan analisanya serta keseuaian alat tersebut dengan judul penelitian. Penelitian yang didasarkan terhadap informasi yang didokumentasikan baik beruupa file, tulisan, berkas, maka dianggap sebagai penelitian yang bersumber pada dokumentasi, sehingga sumber data primer dari penelitian ini adalah dokumentasi (Surachmad, 2010).

\section{PEMBAHASAN}

Dalam pembahasan akan dikategorikan berdasarkan Tingkat Kesalahan, selanjutnya agar memudahkan dalam pembahasan, Sebagai berikut:

1. Tingkat kesalahan analisis berdasar topik dan skala variabel data

2. Tingkat kesalahan penetapan instrumen penelitian berdasar 
topik dan data yang akan di jaring.

3. Tingkat kesalahan dengan mengabaikan validitas dan realiabilitas

Kelengkapan penjelasan di atas, akan diklasifikasikan dalam tabel 1 dibawah ini yang akan menerangkan kesalahan dalam pemilihan analisis. Penelitian dapat dikategorikan dalam berbagai bentuk analisa, yaitu; regression (hubungan), comparemeans (perbedaan), cluster (pengelompokan) (Soebakri, 1992).

Tabel 1. Tingkat Kesalahan Analisis berdasarkan Topik dan Skala Variabel data

\begin{tabular}{lllc}
\hline \multirow{2}{*}{ No } & \multicolumn{1}{c}{ Pilihan Analisis } & $\Sigma$ \\
\hline 1. & Korelasi Product Moment & Korelasi Biserial & 1 \\
2. & Korelasi Product Moment & Korelasi Sperman Rho & 1 \\
3. & Regresi Linier & Anova Dua arah & 12 \\
4. & Regresi Ganda & Anova Dua arah & 8 \\
5. & Korelasi produk Momen & Regresi Ganda & 6 \\
6. & Anova & Regresi Ganda & 2 \\
\multicolumn{2}{c}{ Jumlah } \\
\hline
\end{tabular}

Berdasarkan tabel 1. menujukkan bahwa terdapat varian analisis yang kurang tepat, dalam hal ini menujukkan bahwa banyak mahasiswa yang kurang memahami skala variabel. Mencermati dari tabel diatas pada baris nomor 1 sebanyak 1 tesis yang memilih analisis product momen, namun data yang didapat bukan berskala Rasio dan Interval, namun yang dipilih korelasi product momen. Kemudian pada baris no.2. terdapat satu tesis yang memiliki variabel dengan skala interval dan skala ordinal, namun teknik analisis yang digunakan adalah product momen, seharusnya Spearman Rho.

Pada baris nomor 3 terdapat kesalahan yang dominan, sebanyak 12 tesis menetapkan regresi linier, seharusnya menggunakan anova. Adapun rasional menggunakan Anova karena memenuhi persyaratan yakni membedakan rerata lebih dari dua kelompok data dengan cara membandingkan variansinya. Analisis varian termasuk dalam kategori statistik parametric. Sebagai alat statistika parametric, maka untuk dapat menggunakan rumus ANOVA. Kesalahan ini akan lebih diperparah, karena kesalahan memilih analisis, sekaligus akan melanggar persyaratan uji Anova, yakni, harus terlebih dahulu perlu dilakukan uji asumsi meliputi normalitas, heterokedastisitas dan random sampling. Hal ini juga terjadi pada baris no. 4, yang seharusnya menggunakan Anova dua arah, namun dianalisis dengan menggunakan Regresi linier. Sesunggunya regresi ganda digunakan untuk memprediksi dan melihat sumbangan yang diberikan variabel bebas (prediktor) terhadap varibel terikat (variabel kriterium). Kemudian yang terjadi pada baris no. 5 dan no. 6, sebanyak 6 tesis menetapkan analisis product momen, dan sebanyak 2 tesis dianalisis dengan Anova. Realitas yang sebenarnya ditinjau dari topik dan data yang tersedia memenuhi akan mencari korelasi antara kriterium dengan prediktor, lalu menguji apakah korelasi antara kriterium dengan prediktor itu signifikan, serta ingin menemukan sumbangan relatif antara sesama prediktor. Pembahasan berikutnya menjelaskan tentang kesalahan pemilihan instrumen atau alat penelitian yang dilakukan mahasiswa pascasarjana dalam penulisan tesis-nya, untuk lebih jelasnya dapat dilihat dalam tabel 2 dibawah ini. 
Tabel 2. Tingkat Kesalahan Penetapan Instrumen Penelitian berdasar Topik dan Data yang akan di jaring.

\begin{tabular}{lllc}
\hline \multirow{2}{*}{ No } & \multicolumn{2}{c}{ Pilihan Instrumen Penelitian } & \multicolumn{1}{c}{ Seharusnya } \\
\hline 1. & Angket, observasi dan test, & Test dan skala sikap & 18 \\
2. & Angket, observasi dan skala sikap & Test dan Angket & 11 \\
3. & Observasi dan Test & Skala Sikap dan Test & 2 \\
4. & Observasi dan Angket & Test dan Angket & 2 \\
5. & Skala sikap, observasi dan Test & Test dan Angket & 6 \\
& Jumlah & & 39 \\
\hline
\end{tabular}

Pada baris nomor 1 ditunjukkan bahwa sebanyak 18 tesis mahasiswa menggunakan instrumen, angket, obeservasi dan tes. Sedangkan yang dibutuhkan adalah skala sikap dan tes. Sangat tidak relevan ketika judulnya akan mengungkap sikap responden, namun isntrumen yang digunakan adalah angket. Dengan demikian instrumen tyang digunakan tidak mampu untuk mengungkap sikap. Jika hal ini dipaksakan, tidak dapat mengungkapkan permasalahan penelitian yang sesungguhnya. Pada baris Nomor 1 juga dapat diungkap bahwa terdapat kecenderungan berlebihan ketika menggunakan instrumen. Seharusnya permasalahan penelitian dapat diungkap hanya dengan skala sikap dan tes, justru menambah instrumen berupa observasi.

Selanjutnya seperti yang diuungkap pada pada baris nomor 2 sebanyak 11 tesis menetapkan instrumen penelitian berupa Angket, observasi dan skala sikap, setelah dikonfirmasikan dengan topik penelitian, yang dibutuhkan untuk mengukur adalah tes dan angket. Dengan demikian dapat disimpulkan jika instrumen yang digunakan tidak dapat mengungkap problema penelitian, dan justru bias. Jika diperhatikan kasus yang terjadi pada baris No. 1 dan baris nomor 2 menunjukkan bahwa sering terjadi pemilihan dan pemasangan instrumen penelitian yang berlebihan, dan cenderung tidak efisien. Juga sebagai yang terjadi pada baris nomor 3 , kebutuhan instrumen yang dibutuhkan adalah skala sikap, namun yang dipilih justru observasi. Dari sisi pengungkapan data sesungguhnya tidak terdapat masalah, sikap dapat diambil dari observasi, namun dari sisi efisiensi waktu akan lebih baik jika menggunakan skala sikap. Observasi juga memilki kelemahan tidak dapat menangkap data dengan varian yang banyak, disamping itu pula, untuk kasus-kasus tertentu standarnya lemah.

Pada kasus baris nomor 4, hampir sama yang terjadi pada kasus baris nomor 3, sebanyak 2 tesis menyatakan pilihan instrumen Observasi dan angket, sedangkan kebutuhan rielnya adalah test dan angket. Kemudian pada kasus nomor 5 kebutuhan riil untuk mengungkap problem penelitian seharusnya hanya dibutuhkan instrumen penelitian berupa Tes dan Angket, namun yang dipilih adalah Skala sikap, observasi dan Test. Tentunya disamping tidak memenuhi kriteria efisien dan rasionalitas, justru dapat membiaskan hasil-hasil penelitian.

Berikutnya akan diuraikan tingkat kesalahan pada validitas dan reliabilitas data penelitian yang dilakukan oleh mahasiswa, dimana syarat untuk sebuah instrumen penelitian yang menggunakan kuesioner maka harus dilakukan pengujian awal menggunakan uji validitas dan uji reliabilitas (Sutrisno, 1994), dan dalam tabel 3 akan ditunjukkan datanya: 
Tabel 3. Tingkat Kesalahan dengan mengabaikan Validitas dan realiabilitas

\begin{tabular}{c|cc}
\hline & \multicolumn{2}{c}{ Penggunaan Reliabilitas, dan Validitas } \\
& Validitas & Reliabilitas. \\
\hline Menggunakan & 37 & 37 \\
Tidak & 2 & 2 \\
\hline
\end{tabular}

Dalam penelitian ilmiah dipersyaratkan untuk melakukan validasi terhadap instrumen yang digunakan. Perlu juga dipahami bahwa instrumen yang tidak melalui uji validitas dan realibalitas dapat dipastikan hasil penelitiannya tidak memenuhi kriteria ilmiah. Melalui tahapan validasi, memungkinkan penelitian akan lebih efisien, karena analisis data tepat sasaran, baik substansi, maupun sasaran kesesuaian responden. Dismping itu pula validasi dapat difungsikan untuk mengembangkan alat ukur yang kekinian. Pada Tabel 3. menunjukan hanya sebagian kecil dari tesis yang tidak melakukan uji validitas dan reliabilitas. Dari sebanyak 39 tesis, terdap dua tesis yang tidak melakukan uji validitas dan reliabilitas. Kedua tesis tersebut mengadopsi instrumen yang telah terstandar, namun dalam uraian tidak menyertakan keterangan bahwa isntrumen yang dipakai telah melalui validasi.

\section{KESIMPULAN}

Berdasar pada pembahasan data terungkap berbagai varian kesalahan, mulai penetapaan teknik analisis, pemilihan instrumen serta tingkat pemahaman pentingnya uji validitas dan reliabilitas, dapat dideskripsikan sebagai berikut.

1. Dari analisis isi tergambarkan bahwa pemilihan alat analisis kurang memperhatikan keterkaitan dengan topik penelitian.

2. Pemilihan alat analisis tidak diprediksikan dengan tingkat kebutuhan data.

3. Kurang memahami skala variabel, sehingga cenderung memaksakan alat analisis

4. Terdapat beberapa kerancauan antara pengungkapan problema korelasional dengan problema penelitian yang mengungkap pengaruh variabel antar variable.

5. Kurang pemahaman terhadap pola hubungan pemilihan isntrumen penelitian dengan topik

6. Pemilihan instrumen yang berlebihan, yang pada dasarnya tidak memiliki pengaruh pada hasil, sehingga tidak berguna/tidak digunakan

7. Kesadaran pentingnya uji Validitas dan reliabilitas sangat tinggi.

\section{UCAPAN TERIMA KASIH}

Penulis menyampaikan terima kasih kepada Direktur Pascasarjana yang telah memberikan kesempatan untuk melakukan penelitian serta juga memberikan ucapan beribu-ribu terimakasih pada biro perpustakaan yang membantu memisahkan file-file dan berkas pada tesis yang dipergunakan oleh peneliti dalam riset kali ini. Semoga Tuhan Yang Maha Esa memberikan balasan yang setimpal. 
Djoko Adi W. \& Yitno Utomo : Assessment Penggunaan Alat-Alat Analisis Penelitian Tesis Mahasiswa Pascasarjana Universitas PGRI Adibuana Surabaya

\section{DAFTAR PUSTAKA}

Arifin, Zainal. 2011. Penelitian Pendidikan. Bandung : Remaja Rosdakarya Offset Arikunto, Surharsimi. 2013. Manajemen Penelitian. Jakarta: Rineka Cipta

Efendi, S. dan C. Manning. 1993. Prinsip-Prinsip Analisa Data Metode Penelitian Survey, Jakarta: LP3ES

Ericson, B.H \& Nosanchuk, T.A. C.1981. Memahami Data : Statistik Untuk Ilmu Sosial. Jakarta: LP3ES.

McMillan, James H dan Schumacher, Sally. 20014. Research in Education: A conceptual introduction. New York: Addison Wesley Longman Inc

Soebakri. 1992. Statistik Terapan. Surabaya: FBS-IKIP

Sudjana, Nana. 2007. Penelitian dan Penilaian Pendidikan Bandung: Sinar Baru Algesindo

Sutrisno, Hadi. 1994. Statistik I, II, III, IV. Yogyakarta: Fakultas Psikologi UGM 